Imagined Enemies 
This page intentionally left blank 


\section{Imagined Enemies}

CHINA PREPARES FOR

UNCERTAIN WAR

John Wilson Lewis and Xue Litai

STANFORD UNIVERSITY

STANFORD, CALIFORNIA 
Stanford University Press

Stanford, California

(C) 2006 by the Board of Trustees of the Leland Stanford Junior University. All rights reserved.

No part of this book may be reproduced or transmitted in any form or by any means, electronic or mechanical, including photocopying and recording, or in any information storage or retrieval system without the prior written permission of Stanford University Press.

\section{Library of Congress Cataloging-in-Publication Data}

Lewis, John Wilson, 1930-

Imagined enemies: China prepares for uncertain war/ John Wilson Lewis and Xue Litai. p. $\mathrm{cm}$.

Includes bibliographical references and index. ISBN-13: 978-0-8047-539I-3 (cloth : alk. paper) ISBN-13: 978-0-8047-6103-I (pbk. : alk. paper)

1. China-Military policy. 2. China-Armed Forces. 3. Military planning-China. 4. China-Relations-Taiwan. 5. Taiwan-Relations-China. I. Xue, Litai, 1947- II. Title.

UA835.L428 2006

$355^{\prime} .033551-\mathrm{dc} 22$

2006009400

Typeset by G \& S Typesetters, Inc. in II/I4 Adobe Garamond

Original Printing 2006

Last figure below indicates year of this printing:

$\begin{array}{llllllll}\text { IS I4 I3 I2 II } & \text { IO } & 09 & 08\end{array}$ 
For Mildred Taylor and Yuying Gao 
This page intentionally left blank 